\title{
The Persistent Effect of U.S. Civil Rights Protests on Political Attitudes 10
}

\section{Soumyajit Mazumder Harvard University}

\begin{abstract}
Protests can engender significant institutional change. Can protests also continue to shape a nation's contemporary politics outside of more formalized channels? I argue that social movements can not only beget institutional change, but also long-run, attitudinal change. Using the case of the U.S. civil rights movement, I develop a theory in which protests can shift attitudes and these attitudes can persist. Data from over 150,000 survey respondents provide evidence consistent with the theory. Whites from counties that experienced historical civil rights protests are more likely to identify as Democrats and support affirmative action, and less likely to harbor racial resentment against blacks. These individual-level results are politically meaningful—counties that experienced civil rights protests are associated with greater Democratic Party vote shares even today. This study highlights how social movements can have persistent impacts on a nation's politics.
\end{abstract}

Replication Materials: The data, code, and any additional materials required to replicate all analyses in this article are available on the American Journal of Political Science Dataverse within the Harvard Dataverse Network, at: http://doi.org/10.7910/DVN/WKJJ3Z.

ocial movements are generally associated with periods of massive political and economic change. These movements may spur democratization such as the case with the Velvet Revolution in Czechoslovakia, enfranchise oppressed racial or ethnic groups as seen with the anti-apartheid movement in South Africa, or hasten decolonization as with the Quit India movement in colonial India. Oftentimes, these periods of massive social upheaval tend to be followed by formal institutional change, allowing these movements to lock in their demands past the immediate life of the movement.

Can social movements continue to shape national politics outside of formal institutions? I argue that social movements can engender long-term political change by shifting political attitudes as well. My argument rests on two main theoretical foundations. First, instances of collective action by the protest movement can generate at- titude change among the target public. ${ }^{1}$ Second, historical ideational change persists long after a social movement's life through a system of intergenerational transmission of beliefs. Together, these theoretical premises suggest that social movements can shift public opinion in the long run.

To illustrate the argument, I focus on the case of the American civil rights movement. This case provides theoretical and empirical leverage for several reasons. First, the U.S. civil rights movement was a watershed moment in U.S. history, making it of particular relevance for studying the long-term ramifications of historical social movements. Second, the U.S. civil rights movement was not only focused on institutional change and the end of Jim Crow, but also was concerned with fundamentally reshaping American values as they related to race. Third, the civil rights movement has minimal organizational

Soumyajit Mazumder is Ph.D. Candidate, Department of Government, Harvard University, 1737 Cambridge Street, Cambridge, MA 02138 (smazumder@g.harvard.edu).

I would like to thank Bill Jacoby and the three anonymous reviewers at the American Journal of Political Science for their tough, thoughtful, and constructive feedback. I am indebted to Matt Blackwell, Riley Carney, Ryan Enos, Jeff Frieden, Claudine Gay, Jennifer Hochschild, Dan de Kadt, Desmond King, Dominika Kruszewska, Nathan Nunn, Michael Olson, Jim Robinson, Jon Rogowski, Steve Wilkinson, and Teppei Yamamoto for their conversations, feedback, and encouragement on this project. I also thank participants of the American Politics and Political Economy Research Workshops at Harvard University for helpful comments and discussions on this project. Additionally, I would like to thank audiences of the 2016 Politics and History Workshop at Princeton University and the 2017 Meeting of the International Society of Political Psychology for productive discussions and feedback on this project. The usual disclaimers apply.

[Correction added on 9/17, after first online publication: A correction has been made to Figure 2 and 3.]

${ }^{1}$ In this piece, I refer to whites as the target public within the context of the civil rights movement. I outline this concept in greater detail in the Theory section.

American Journal of Political Science, Vol. 62, No. 4, October 2018, Pp. 922-935

(C)2018, Midwest Political Science Association

DOI: 10.1111/ajps.12384 
legacies relative to other social movements in history, making this a harder case to find persistent attitudinal effects. $^{2}$

Using cross-sectional, historical data on U.S. civil rights protests during 1960-65 combined with contemporary public opinion data, I find that whites from counties that experienced civil rights protests tend to be more liberal today, especially with respect to racial attitudes. They indicate greater support for affirmative action, display less racial resentment, and are more likely to identify as Democrats than whites from counties that did not experience protests. These results hold after accounting for a variety of different alternative explanations and state fixed effects. Using a sensitivity analysis procedure, I find that the selection process would have to be about two times more powerful than protest activity as well as other major observable confounders such as urbanization, percent black, income levels, and state-level differences. Given the historical literature on the civil rights movement, which suggests that protesters targeted racially conservative areas, it is unlikely that the most plausible selection story-that protesters targeted liberal counties-would explain away the entirety of my findings (Arsenault 2006; McAdam 1999; Mickey 2015). Furthermore, civil rights protests seem to have a concrete political effect: Counties that experienced protests have had higher vote shares for the Democratic Party over the past 40 years. These results cannot be explained by differential white out-migration or increases in black turnout following the passage of the Voting Rights Act. As a whole, the results suggest that civil rights protests seemed to have left a deep political legacy in the United States beyond its institutions.

This article speaks to several literatures. For those interested in American politics, this article complements recent work by Acharya, Blackwell, and Sen (2016) on the legacy of slavery in America. They find that the institution of slavery continues to have an effect on contemporary American politics. Similarly, I show that demonstrations of collective action can also create persistent cultural change. The important caveat that I find is that the attitudes propped up by the Jim Crow racial order can be reshaped through instances of nonviolent mobilization. Given the competing white supremacist and racial egalitarian orders throughout American political development, I provide a theory that places social movements as a key lever in moving from one racial order to another during critical points in which these two orders are in deep tension (King and Smith 2005, 2011). Broadly speaking,

${ }^{2}$ By organizational legacies, I mean vestiges of the civil rights movement's infrastructure that take the form of political parties or formal interest groups. this article speaks to those interested in the politics of race in America by highlighting the central role of protest and social movements in the transformation of race relations in the United States (Key 1949; King and Smith 2005, 2008, 2014; Tesler 2013). The results imply that mass political movements can have a persistent impact on racial politics beyond the immediate life of these movements.

\section{Theory}

How can protests that happened over half a century ago continue to shape political attitudes today? In this section, I provide a theory of how nonviolent protests can reshape attitudes over the long run within the context of the U.S. civil rights movement. Throughout the rest of the article, I refer to whites as the target of the civil rights movement. Given the context of the time, the segregationist and discriminatory institutions highly racialized the nature of political and economic institutions in the United States prior to reforms such as the Civil Rights Act and the Voting Rights Act. As such, the institutions were founded on a notion of the superiority of whites over blacks (King and Smith 2005). With this blending of white supremacist ideology into the institutions that maintained such a hierarchy, the civil rights movement targeted not only the institutions of white supremacy and Jim Crow, but also the underlying racist beliefs that many whites held at the time (Moland 2002). To briefly summarize the theory before highlighting the evidence supporting each step of the argument, I argue that nonviolent protests can induce the target public (whites) to increase their support for the protesting group (African Americans). Particularly, the priming of identities that exist beyond race, persuasion, and strategic signaling provides plausible paths through which nonviolent protests can shift attitudes and reduce prejudice against the protesting group. These beliefs persist through processes of intergenerational transmission of political attitudes and values. An alternative to this theory is that protests induce differential migration, which may drive geographic polarization in political and racial attitudes. I also discuss this potential mechanism and why it is insufficient to explain how protests can leave a persistent political legacy.

\section{A Theory of Civil Resistance and Long-Run Attitudinal Change}

Protests, particularly peaceful ones by African Americans, can shift whites' political preferences through a number of psychological and informational mechanisms. Drawing 
on work from psychology and in particular the common ingroup identity model proposed by Gaertner and Dovidio (2000), I argue that the ways in which protests prime identities beyond race, such as being American, can help to reduce prejudice against blacks. Several studies find evidence consistent with this psychological model. Gaertner et al. (1989) show that experimentally inducing participants to recategorize their ingroup identity into just one group instead of multiple groups reduced prejudice against former outgroup members. Gaertner (1996) provides evidence using surveys of students from multiethnic high schools, executives who experienced corporate mergers, and a field experiment with college sports fans that transforming "us" versus "them" relationships into "we" relationships reduces prejudice by ingroup members against the outgroup. This type of priming can reduce prejudice with respect to highly salient identities such as race and partisanship. Transue (2007) shows that experimentally manipulating white respondents to feel closer to their American national identity increased their support to fund public programs that would help minorities. With respect to partisanship, Levendusky (2018) shows that priming American national identity substantially reduces affective polarization between partisans. In short, the evidence suggests that invoking broader identities can reduce prejudice toward outgroups. Moreover, this type of identity priming could have also led whites to identify more closely with African Americans (Craemer 2008). By leading whites to feel closer to African Americans, this could have also reduced prejudice against African Americans (Craemer 2010). In the case of the civil rights movements, exposure to protests, which emphasized more transcendent identities and the ways in which whites and African Americans are connected, can plausibly reduce whites' prejudice against African Americans. ${ }^{3}$

The literature on political psychology and persuasion also demonstrates that even the types of communication that do not amount to a massive social movement such as the civil rights movement can still durably shift political attitudes. Broockman and Kalla (2016) find that even a short conversation related to discrimination against transgender persons can make individuals more sympathetic toward transgender rights and that these effects persist for a significant amount of time. Similarly, Paluck and Green (2009) find that media programs aimed at

\footnotetext{
${ }^{3}$ For example, Martin Luther King Jr.'s "I Have a Dream" speech concluded on the importance of the shared identities between whites and blacks. These types of appeals, of course, were not the only ones that African Americans used. Others, such as Malcolm $\mathrm{X}$, appealed to black nationalist rhetoric. Regardless, these types of appeals to shared or overarching identities were not uncommon.
}

shifting attitudes toward the government were successful in doing so. Given that the civil rights movement waged a massive effort at shifting the minds of Americans, we should expect that some of these psychological mechanisms should be operating perhaps even more acutely as protesters quite explicitly invoke symbols and cues that provide a more vivid understanding about the true state of black oppression in the United States.

Aside from psychological mechanisms, there could also be informational channels through which protest influences political attitudes. Chenoweth and Stephan (2012) argue and show how nonviolent civil resistance provides information to the broader public about a group's true intentions. By engaging in peaceful resistance such as sit-ins, protest rallies, boycotts, and civil disobedience, protesters provide information about their willingness to bargain as well as the sincerity of their demands (Chenoweth and Stephan 2008). This is because protesters open themselves to repression, which sends a costly signal to the broader public. For instance, protesters during the civil rights movement, for the most part, remained peaceful in spite of mass arrests, beatings, and harassment by local authorities and hate groups. After witnessing these types of costly actions by protesters, whites could have updated their beliefs about African Americans by discerning the sincerity of the protesters' demands. This informational channel, then, suggests that whites could have become more sympathetic to African Americans' demands after witnessing a sustained, nonviolent movement that experienced, oftentimes, brutal repression by both local authorities and vigilante groups. Thus, protests have several different channels-psychological, persuasion, or informational-through which they can influence political attitudes and public opinion.

Work from the social movements literature provides evidence consistent with the broader notion that protests can shift public opinion. Wasow (2017) shows that peaceful civil rights protests seemed to have increased Democratic Party vote shares, whereas violent ones led to reductions in Democratic Party vote shares in the 1964, 1968, and 1972 U.S. presidential elections. Moreover, Gillion (2012) finds that minority-led protests also changed congressional voting behavior toward the preferences of the protesters. More generally speaking, protest movements across a variety of areas, such as social policy, women's issues, anti-war protests, and immigration, seem to be able to shift both elites and the public toward the protester's preferences (Branton et al. 2015; McAdam and Su 2002; Soule and Olzak 2004; Wallace, Zepeda-Millan, and Jones-Correa 2014). Using plausibly exogenous variation in protest attendance from rain shocks, Madestam et al. (2013) show that the Tea Party movement was able 
to shift beliefs toward becoming more conservative and favorable toward the Tea Party. The overall implication from this discussion is that there is significant evidence that protests do seem to be able to shift public opinion, at least in the short run.

These attitudes can persist through processes of intergenerational socialization. Boyd and Richerson (2005) and Tabellini (2008) provide models of cultural evolution that demonstrate how parents have incentives to inculcate their children with cultures and attitudes similar to their own. Particularly, the literature in political economy and cultural economics provides significant cross-national, empirical evidence as to the way in which historical shocks can generate cultures and beliefs that persist into contemporary times. For example, Voigtlander and Voth (2012) show how exogenous variation in pogroms against Jews during the Black Death led to persistent anti-Semitism in pogrom-affected areas in Germany. In the case of Africa, Nunn and Wantchekon (2011) find that ethnic groups that experienced greater levels of historical slave exports are now less trusting of each other.

In the American context, the idea that attitudes can persist through intergenerational socialization is quite prominent. Classic works such as Campbell et al. (1960) and Zaller (1992) show how ideology and partisanship tend to be transmitted from parent to child. Not only do parents transmit their partisanship to their children, but these identities also tend to be remarkably stable across time (Green, Palmquist, and Schickler 2002). Recently, scholars have shown how various cultures and attitudes outside of partisanship persist as well. Several scholars find evidence demonstrating the persistence of a "culture of honor" in the U.S. South (Nisbett and Cohen 1996). Recently, Acharya, Blackwell, and Sen (2016) showed how the historical legacy of slavery continues to shape whites' attitudes toward African Americans. Moreover, Acharya, Blackwell, and Sen (2016) use data from the Youth-Parent Socialization Panel Study to show that the correlation between an individual and that individual's parent's racial attitudes is fairly high and remarkably stable over the life course. Importantly, the institutional context of the society must be able to sustain these beliefs (Tabellini 2008). Within the context of racial attitudes, King and Smith (2005) show how the movement toward more egalitarian racial orders might be the underlying institutional context needed to sustain more liberal racial attitudes over the long run. Thus, attitudes can persist across a wide variety of settings so long as the institutional context can sustain these attitudes.

The upshot of these two steps to my argument suggests that there is a plausible path for civil rights protests to persistently change political attitudes. In short, areas that experienced civil rights protests in the early 1960s, where the vast majority of protests were peaceful in nature, shifted political attitudes to become more liberal on racial issues. This could have happened either through invocation of common identities, persuasion, signaling, or some combination of all of these mechanisms. These attitudes persisted across subsequent generations through intergenerational socialization. Thus, we should be able to detect the attitudinal effects of the civil rights movement even today.

This theory does not discount the possibility that protests sparked white backlash. Predictions from group dominance and symbolic politics models of intergroup relations could suggest that protests can spark whites to become even more prejudiced or not change at all if they view a threat to their status or that protesters shift whites to substitute explicit racism for more implicit forms (Sears and Henry 2003; Sidanius and Pratto 1999). If the forces from the psychological, persuasion, and informational channels described above dominate, however, then we should still see declines in racial prejudice in the long run despite the potential for backlash. Moreover, the choice between violence and nonviolence as a tactic carried a great deal of complexity. Though violent protests can be a potentially effective way to achieve institutional change, the literature suggests that violence can have a negative effect on public opinion (Chenoweth and Stephan 2012; Wasow 2017). In the context of this article, however, I argue that nonviolent protest has the greatest chance of leaving a durable, attitudinal legacy.

A few brief anecdotes on the legacy of the civil rights movement in the U.S. South-where racism was particularly overt through Jim Crow-provide some evidence that individuals might have actually changed their attitudes toward African Americans. Writing about the ways in which the civil rights movement impacted ordinary farmers in the South, historian Jason Sokol recounts the experience of one such individual:

When the civil rights movement tore through the southern landscape in the 1950s and 1960s, it challenged the attitudes of millions, undermined their customs, and upended their ways of life. It even penetrated the minds of old farmers like Wilson. "I began to get a lot older before I began to realize." He attributed fundamental changes in his racial beliefs to the civil rights movement. "Honest to God when I was a kid, I believed that junk," Wilson recalled in 1974 . "I changed ... an awful lot of my attitude ... toward matters of race." Wilson did not count his experience as unique; he glimpsed similar 
changes in many of his neighbors. "These ... farmers around here... and their wives, not all of them but by and large, they have come a long damn way." (Sokol 2007, 3)

These types of changes were also present among some of those who were actively complicit in the Jim Crow racial order. Economic historian Gavin Wright recounts the experience of Joe Smitherman, mayor of the infamous Selma, Alabama: "My hands are as dirty as the others. I ordered the arrest of Dr. King. We were wrong. I did it. I'm sorry" (Wright 2013, 5). While these statements are from only two individuals who lived through the civil rights movement, they demonstrate that the civil rights movement seemed to at least have opened their eyes toward the plight of African Americans in the United States. Thus, they provide some initial plausibility to the notion that individuals could have changed their beliefs in response to protest, even in places where racism was particularly acute. Of course, these stories are only anecdotes and do not allow us to assess whether these changes are truly indicative of a wider shift in attitudes in areas affected by the civil rights movement. To determine whether these types of changes in beliefs might have been part of a more systematic process of attitude change, I rely on the econometric analysis provided in the Research Design section.

\section{Alternative Mechanism: Sorting and Geographic Polarization}

The major alternative mechanism that would explain the persistence of the U.S. civil rights movement's effect on contemporary American politics suggests a bleaker story. This alternative mechanism hypothesizes that the civil rights movement led to racial sorting via white outmigration-a story consistent with the racial threat literature in American politics (Enos 2016; Key 1949). For the migration mechanism to work, protests should have induced attitudinal sorting. Since not all whites developed favorable attitudes toward African Americans during the civil rights movement, it could be the case that the more steadfastly conservative whites migrated out of counties with protest activity.

The first step of this explanation suggests that civil rights protests should have led to a specific kind of racial segregation that was ideological in nature. Given white opposition to the dismantling of the white supremacist Jim Crow institutions, these protests could have led to the migration of conservative whites away from these protestaffected areas to areas such as the suburbs-provided that the costs of moving were not prohibitively high. Next, these whites who moved away must have stayed in these new locations until today. It is unclear whether this phenomenon of "white flight" can explain the results that I find since much of it happened well before the time period that I analyze (Nall 2015). Moreover, Mummolo and Nall (2016) show that political motivations for geographic sorting do little to explain the reasons why individuals decide to live in one location over another. This suggests that these sorting effects should be small relative to the attitudinal change effects. The results that I present in the next section provide evidence consistent with this.

\section{Research Design Data Sources and Variables}

Contemporary Public Opinion. The outcome variables tap into various dimensions of racially liberal attitudes. I operationalize each outcome variable using the same scheme as Acharya, Blackwell, and Sen (2016), subset the data to whites since they are the set of individuals for which the theory applies, and pool survey data from the Cooperative Congressional Election Study (CCES) across the years 2006, 2008, 2009, 2010, and 2011 (over 157,000 white respondents). First, I measure a respondent's level of racial resentment-a concept that captures whites' prejudice against African Americans. ${ }^{4}$ The CCES has two items that measure this concept: (1) "The Irish, Italians, Jews and many other minorities overcame prejudice and worked their way up. Blacks should do the same without any special favors"; and (2) "Generations of slavery and discrimination have created conditions that make it difficult for Blacks to work their way out of the lower class." Individuals can indicate whether they strongly agree, somewhat agree, neither agree nor disagree, somewhat disagree, or strongly disagree for each statement. I average these two questions into one index that runs from 1 to 5, with higher values indicating more racial resentment toward African Americans. Next, I measure an individual's support for affirmative action. While support for affirmative action is not a perfect measure of racial attitudes, it does tap into the ways in which whites are willing to support policies that explicitly benefit minorities. Whites who responded that they "somewhat support/strongly support" affirmative action receive a value

${ }^{4}$ Racial resentment or symbolic racism captures the ways in which whites' prejudice against African Americans is purposely confounded with an abstract belief system to justify one's views toward African Americans as a group. For a more detailed discussion of the merits and potential problems with this concept, see Sniderman and Tetlock (1986), Henry and Sears (2002), and Sears and Henry (2003). 
of 1 , whereas the rest receive a value of 0 . Finally, I measure an individual's identification with the Democratic Party. While the Democrats used to be the party synonymous with Jim Crow, it is now the party most supportive of race issues as they relate to African Americans (Shickler 2016). Thus, I argue that identification with the Democratic Party can be viewed as another measure of support for racial liberalism. ${ }^{5}$ To allow for more conservative inferences, I aggregate all of these measures to the county level-the level at which protests are measured (Green and Vavreck 2008). ${ }^{6}$ Thus, the final outcome data measure either the average level of racial resentment of whites, the proportion of whites who support affirmative action, or the proportion of whites who identify as Democrats today in a given county.

Civil Rights Protests. The logic of my argument implies that demonstrations of collective action in the form of civil rights protests could have long-term political consequences. I use data from the Dynamics of Collective Action data set, which records demonstrations of collective action from 1960 to 1965 using articles from the New York Times. ${ }^{7}$ From these data, I extract all civil rights protest events from the years 1960-65. I stop the data collection on protests in 1965 with the passage of the Voting Rights Act (VRA) so that my results do not pick up any institutional changes brought about by the VRA. I then map the city of each protest onto that city's respective county so as to generate county-level indicators.

I use the county as the main unit of analysis for several reasons. First, it is the lowest level of aggregation for which I have consistent information on all variables across the main data set. Second, counties also capture the level at which I can measure the local impact of civil rights protests. Though the civil rights movement was clearly a national movement with national consequences, the intensity of the protest effect should be greater among areas more geographically proximate to the protest. As such, the county captures to the best degree possible the ways in which local legacies of the civil rights movement might persist. ${ }^{8}$

\footnotetext{
${ }^{5}$ Though it can certainly be the case that Independents can have racially liberal views, the Democratic Party's stated commitment to issues that face minorities provides a measure of formalized support for racial liberalism.

${ }^{6}$ I take the weighted means by county using the CCES sample weights. Since I am using individual-level data from the CCES to compute estimates of county-level racial attitudes, the ecological fallacy is not a problem here.

${ }^{7}$ The data can be accessed at http://web.stanford.edu/group/ collectiveaction/cgi-bin/drupal/.

${ }^{8} \mathrm{I}$ discuss potential reporting biases in the supporting information.
}

I primarily operationalize my main independent variable — civil rights protests-as a binary indicator variable for whether a given county received a protest "treatment" to facilitate ease of interpretation. On average, approximately $9 \%$ of all counties in the United States received a protest "treatment." Figure 1 shows the distribution of protests across counties.

\section{Empirical Strategy Selection on Observables}

To assess whether historical civil rights protest activity is associated with contemporary racial attitudes among whites, I estimate a series of ordinary least squares (OLS) regressions that rely on a selection on observables assumption — that protests are "as-if" random conditional on a set of pretreatment covariates-to identify the effect of historical protests on contemporary political attitudes. This is a strong assumption to make since groups do not experience protests randomly. In this case, then, it is important to probe this assumption using sensitivity analyses and assess to what degree the results rely on the conditional independence assumption. I demonstrate with a sensitivity test that my results do not rely on this assumption and that the most plausible type of confounding is likely to lead this design to underestimate the effect of protests. Thus, I estimate a series of equations of the following form:

$$
Y_{i}=\beta \text { Protest }_{i}+\gamma X_{i}+\delta S_{i}+\epsilon_{i}
$$

$Y_{i}$ represents the main outcome variables of interest. $\beta$ captures the effect of having a Protest in county $i$ on political attitudes. The coefficient $\gamma$ on $X_{i}$ captures the effect of historical pretreatment control variables such as a county's percent urban population, percent black population, and median household income, as well as the average vote share for the Democratic Party from 1932 to 1956, among other socioeconomic and demographic covariates taken from the 1960 and 1962 U.S. Census (Haines, n.d.). The term $\delta S_{i}$ captures a vector of state-level fixed effects. These state-level fixed effects are important for identification since states tended to enact discriminatory policies to varying degrees. Finally, $\epsilon_{i}$ represents the error term. For inference, I use heteroskedastic robust standard errors.

The key identifying assumption is that the assignment of Protest should be plausibly exogenous conditional on these variables. Adjusting for the main observables such as urbanization, percent black, and income should remove the main economic and demographic factors that simultaneously influence protests and contemporary voting 


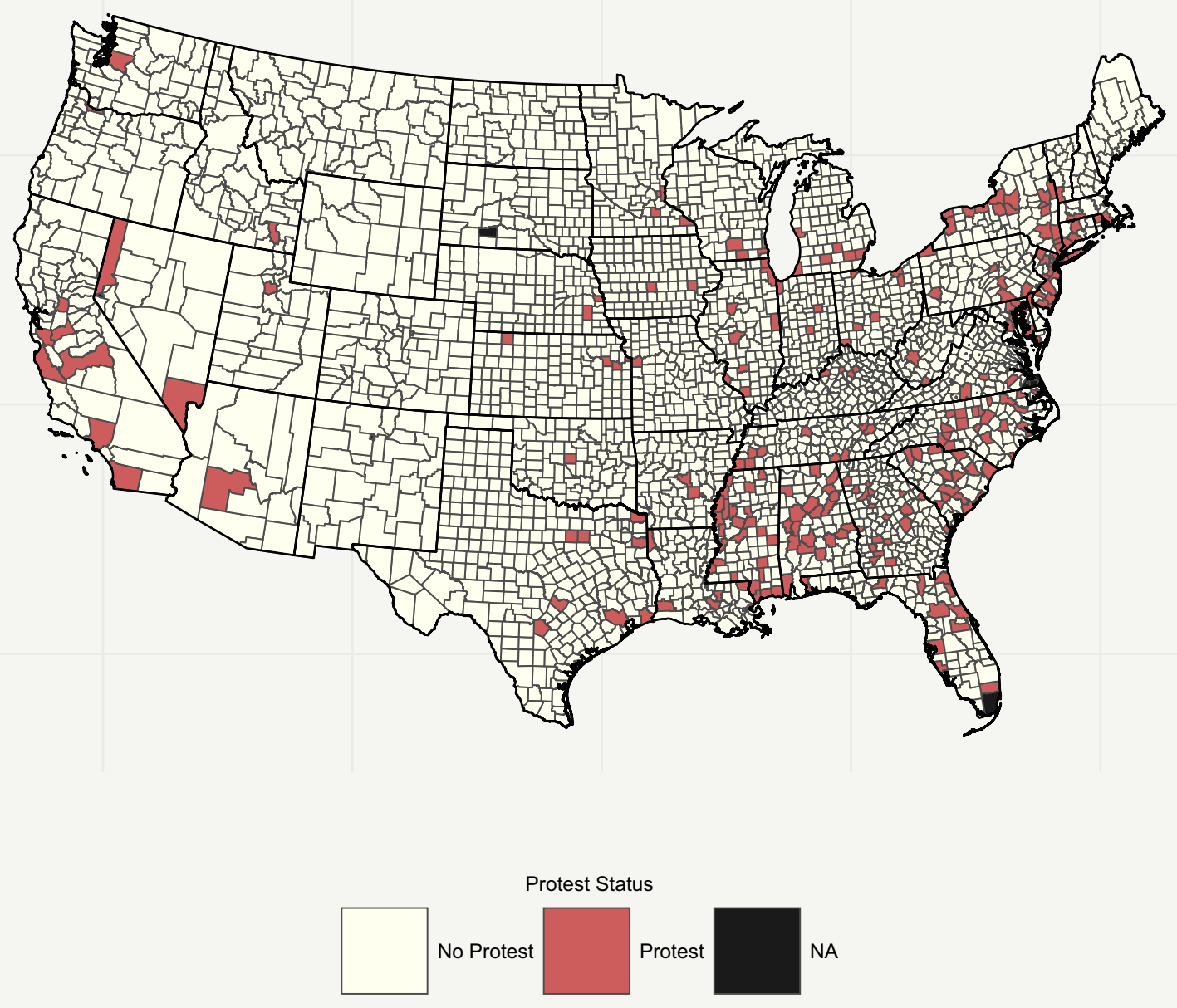

behavior. Moreover, adjusting for the average Democratic Party vote share from 1932 to 1956 should remove some of the confounding that could occur from protesters' targeting areas based on underlying political values. To explore the plausibility of this assumption, I use a number of robustness checks, such as including a more exhaustive set of historical control variables and a sensitivity analysis, as suggested by Blackwell (2014). Importantly, my results are insensitive to the inclusion of additional potential explanations as well as to the exogeneity assumption.

\section{Main Results: Protests Are Associated with Less Racial Prejudice Today}

Are historical protests during the civil rights movement associated with more liberal racial attitudes today?
Table 1 indicates consistent support for the theory. Whites from counties that experienced civil rights protests over 50 years ago are less likely to harbor racial resentment against African Americans, more likely to support affirmative action, and more likely to identify as Democrats today. These effects are all significant at the $\mathrm{p}$ $<.05$ level. Substantively, these effects are equivalent to moving from the average level of racial resentment and support for affirmative action in the South to roughly the average level of these variables in the Midwest. In terms of partisan identity, the results indicate that whites from protest counties are nearly 3\% more likely to identify as Democrats. This effect is substantively similar to moving from the average level of Democratic partisanship in a Deep South state such as Georgia to a Midwest state such as Kansas. Given that these protests occurred over 50 years ago and that organizations central to the civil rights movement, such as the Southern Christian Leadership 


\section{TABLE 1 Effect of Historical Civil Rights Protests on Contemporary Political Attitudes, OLS}

\begin{tabular}{lccc}
\hline & $\begin{array}{c}\text { Racial } \\
\text { Resentment } \\
\text { Model 1 }\end{array}$ & $\begin{array}{c}\text { Affirm. } \\
\text { Action } \\
\text { Model 2 }\end{array}$ & $\begin{array}{c}\text { Prop. } \\
\text { Democrat } \\
\text { Model 3 }\end{array}$ \\
\hline Protest & $-0.090^{* *}$ & $0.020^{*}$ & $0.028^{*}$ \\
& $(0.034)$ & $(0.009)$ & $(0.012)$ \\
State Fixed Effects & $\sqrt{ }$ & $\sqrt{ }$ & $\sqrt{ }$ \\
1960 Controls & $\sqrt{ }$ & $\sqrt{ }$ & $\sqrt{ }$ \\
N & 2,530 & 2,865 & 2,865 \\
R-squared & 0.212 & 0.153 & 0.285 \\
\hline
\end{tabular}

Note: Outcome variables are county averages among whites from the $2006-11$ CCES. ${ }^{* * *} \mathrm{p}<.001,{ }^{* *} \mathrm{p}<.01,{ }^{*} \mathrm{p}<.05$.

Coalition, no longer have a formal political presence, these results provide evidence suggesting that protests can persistently shape a nation's political attitudes. ${ }^{9}$

I also perform a variety of different robustness checks of the effect of protests on whites' racial attitudes today. First, I reestimate the specification from column 1 of Table 1 and use the $\log (x+1)$ transformation of the number of protests. The point estimate of the number of protests remains negative, statistically significant, and stable across all models. Next, the control variables in the models presented in Table 1 might not adequately capture potential alternative explanations. To assuage this concern, I reestimate the effect of protests on racial resentment and sequentially add in controls for labor force, demographics, and urban structure that tap into how various grievances might jointly explain protests and attitudes. The results show that the effect of protests on whites' racial resentment remains negative and statistically significant. Additionally, I also code and control for the presence of Ku Klux Klan (KKK) chapter locations from reports made by the House Un-American Activities Committee and the historical prevalence of slavery in a county in 1860 to proxy for other local elements of Jim Crow that are not captured by the state fixed effects. ${ }^{10}$ The point estimates on all of the outcomes remain unchanged and statistically significant even

${ }^{9}$ While protests could have induced backlash especially following the VRA and black enfranchisement, these results suggest that, on average, individuals from protest counties seem to be more racially liberal than ones from nonprotest counties. Unfortunately, the lack of panel data makes it difficult to ascertain potential backlash effects induced by the interaction of VRA implementation and protests.

${ }^{10}$ The raw reports from the House Un-American Activities Committee can be found here: https://catalog.hathitrust.org/ Record/007043524. when accounting for all of these potential alternative explanations. Moreover, protesters could have targeted areas that had more media access so as to increase media exposure, and these same places could also be more racially liberal. To assuage this concern, I use data on television ownership per household at the county level and find that my results remain substantively unchanged and statistically significant (Gentzkow 2006). To assess effect heterogeneity, I use Bayesian LASSO to assess the heterogeneity of the estimated effect with respect to percent black, urbanization, income, and South versus non-South, among other variables (Ratkovic and Tingley 2017). The effects seem to be particularly pronounced in high urbanization areas, indicating some evidence the effects seem to persist most in areas with denser populations. Finally, I use randomization inference to account for potential arbitrary spatial correlations. The results remain robust to this analysis. Thus, the main results are robust to major alternative explanations and do not rely on particular models or inference procedures.

\section{Sensitivity to Unobserved Selection}

While I demonstrate that my results are not sensitive to variable operationalization or accounting for additional alternative explanations, a major threat to inference is that there are unobservable confounds that simultaneously affect protests and contemporary political attitudes. To assess the sensitivity of these results to the selection on observables assumption, I use a test outlined by Blackwell (2014). This test assesses the sensitivity of a treatment effect to an unobserved confound by examining how large of an effect such an unobservable would have to have to explain away the entirety of the estimated effect. I show the results of the sensitivity checks in Figures 2 and 3.

Figures 2 and 3 both provide evidence that the main results on racial resentment are not particularly sensitive to the identifying assumption. Specifically, Figure 2 provides evidence that the strength of the raw confounding must be more than two times greater than the effect of protests in order to explain away the results. Figure 3 shows that such an unmeasured variable would have to explain more than twice the amount of variance in racial resentment than observable predictors such as urbanization, median income, and percent black. Similarly, such a variable would have to have the same explanatory power as all of the state fixed effects combined. ${ }^{11}$ Together, these sensitivity checks provide evidence that

\footnotetext{
${ }^{11}$ Alternative explanations/confounders to the right of the vertical
} axis would be consistent with a story in which protesters target the 


\section{FIgURE 2 Sensitivity of Racial Resentment Effect to Selection on Unobservables: Raw Confounding}

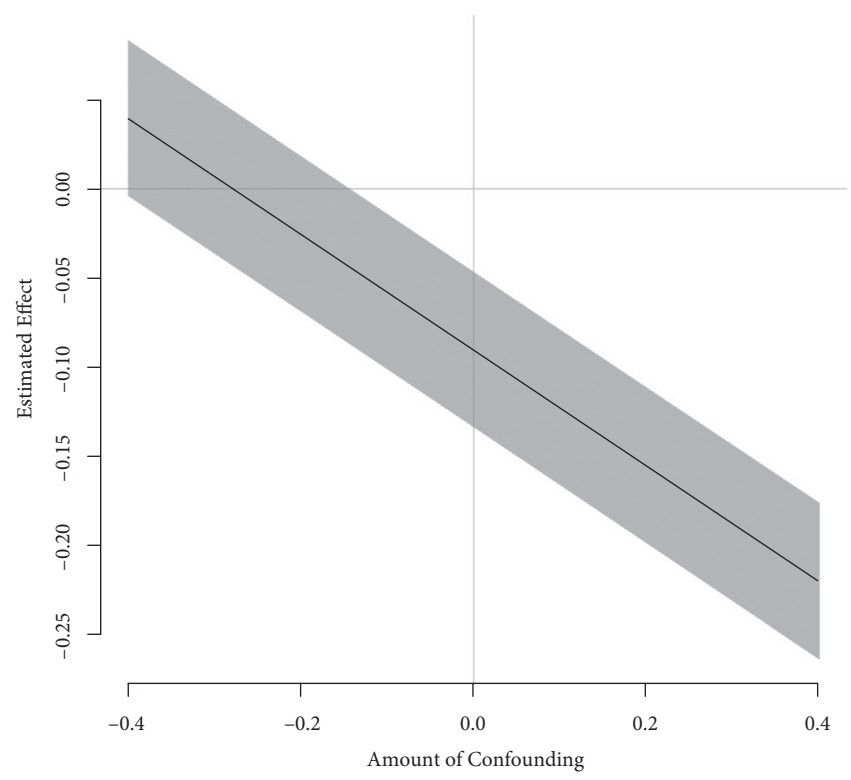

Note: Shaded band represents $95 \%$ confidence intervals.

the estimated effects do not rely on the exogeneity assumption.

Given the historical setting, it is difficult to think of an unobservable confound that has such a large effect. While the most plausible story is that protesters simply selected areas that were more liberal back then, this goes at odds with much of the historical literature on the civil rights movement; rather, historians point out that protesters seemed to target areas where racism was especially pernicious (Arsenault 2006; McAdam 1999; Mickey 2015). That is, protesters engaged in collective action precisely where their grievances were acute. Since protesters seemed to have targeted the most conservative areas, it is more likely the case that the results are downward biased. Therefore, I argue that the results are consistent with a causal relationship between historical protests and contemporary political attitudes.

\section{Protests Impact Support for the Democratic Party}

Do these attitudinal shifts translate into any observable impact on political behavior? To assess whether historical protests led to behavioral shifts, I reestimate the model

most racially resentful places, whereas confounders to the left of the vertical axis would represent situations in which protesters target the least racially resentful places.

\section{FIGURE 3 Sensitivity of Racial Resentment Effect to Selection on Unobservables: Variance Explained by Confounding}

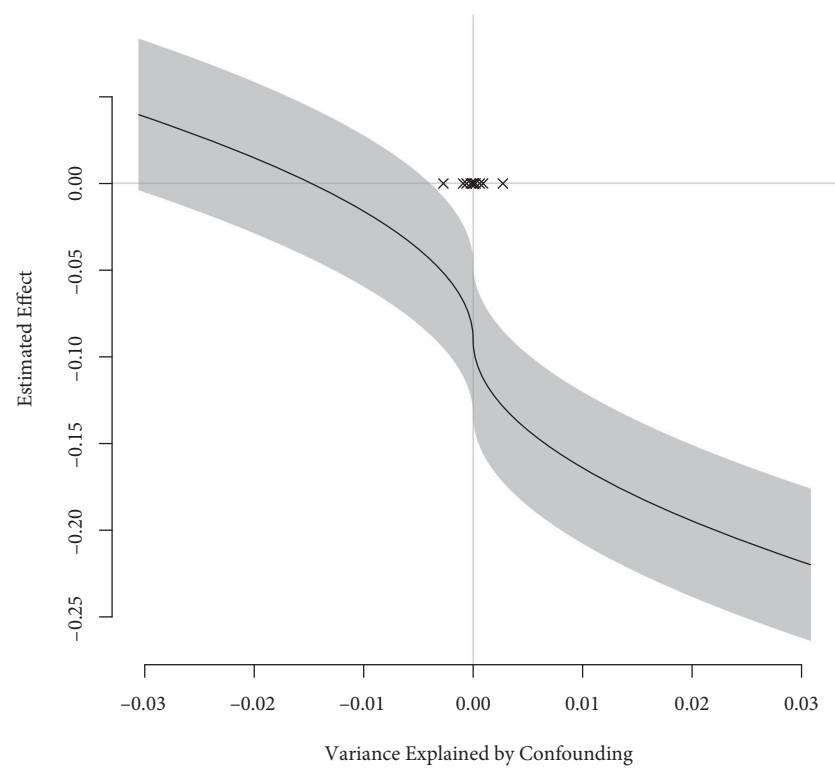

Note: Shaded band represents $95 \%$ confidence intervals.

represented in Equation (1) and use the Democratic Party's presidential vote share in each presidential election year from 1960 to 2012. Given the Democrats' association with civil rights and minority voters following the end of realignment in 1968, this measure largely captures the public's support for left-wing issues particularly as they relate to racial issues (Schickler 2016). I present the results of this exercise in Figure 4.

The results provide support for the notion that these attitudinal changes translated into behavioral changes as they relate to electoral politics. During the 1960 and 1964 elections (Kennedy and Johnson, respectively), the initial effect of protests is statistically indistinguishable from zero. With the 1968 election (Nixon), the effect becomes positive. This effect drops for the 1976 (Carter) and 1980 (Reagan) elections and then rises back up over each following election. Finally, the effect of protests on Democratic Party vote shares reaches its maximum during Obama's initial election (2008) and reelection (2012). These basic patterns are consistent with a story in which, following the realignment of Democrats into the racially liberal party, the Democrats receive an added gain in elections in which race is particularly salient. As with the core public opinion analysis, I also assess the sensitivity of these results to unobserved explanations and find that the results are not particularly dependent on the conditional independence assumption. Using estimated black voter registration rates today from the CCES's validated voter 


\section{Figure 4 Effect of Protests on Democratic Party Vote Shares over Time}

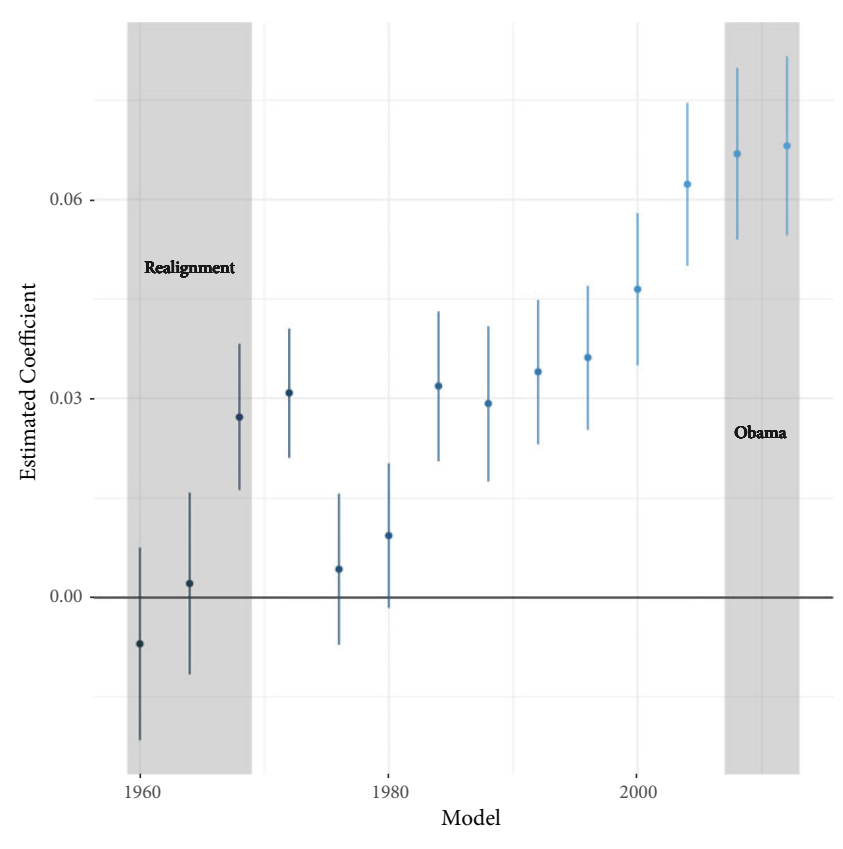

Note: Error bars represent 95\% confidence intervals. Models estimated using OLS with state fixed effects and controlling for socioeconomic and demographic controls with heteroskedastic robust standard errors.

registration item, I also find that these electoral results are not driven by differential black voter registration today. While these results are of course suggestive, they do provide evidence consistent with the notion that protests could have led to behavioral changes among whites.

\section{Did Protests Induce Geographic Polarization?}

An alternative mechanism that might explain the findings is that protests led to white out-migration. Thus, protests may not actually continue to shape contemporary American politics through attitudinal change; instead, protests actually led to more polarization, which would explain why protest counties are now more liberal than their nonprotest counterparts today.

I use county-level migration data to estimate the effect of protests on white out-migration (Winkler et al. 2013). If the results are driven by racially based political sorting, then we might expect protests to lead to white out-migration from these protest counties. Thus, I estimate OLS equations with the main independent variable being the Protest indicator in addition to
TABLE 2 Effect of Historical Civil Rights Protests on White Migration, OLS

\begin{tabular}{lcc}
\hline & $\begin{array}{c}\text { Net White } \\
\text { Migration, 1960 } \\
\text { Model 1 }\end{array}$ & $\begin{array}{c}\text { Net White } \\
\text { Migration, 1970 } \\
\text { Model 2 }\end{array}$ \\
\hline Protest & -41.579 & $-152.694^{* * *}$ \\
State Fixed Effects & $(33.718)$ & $(42.648)$ \\
1960 Full Controls & $\sqrt{ }$ & $\sqrt{ }$ \\
N & 2,821 & $\sqrt{ }$ \\
R-squared & 0.321 & 2,826 \\
\hline Note: ${ }^{* * *} \mathrm{p}<.001,{ }^{* *} \mathrm{p}<.01,{ }^{*} \mathrm{p}<.05$. &
\end{tabular}

historical confounders and state fixed effects, with net white migration between 1960 and 1970 as the dependent variable.

I present the results in Table 2. While I do not find that counties that experienced civil rights protests had differential white migration levels in 1960, I do find that protest-affected counties seemed to have generated a small degree of net white out-migration in the 1970s. Counties that experienced civil rights protests had a net white out-migration rate of about 153 individuals relative to nonprotest counties-a substantive effect that is quite small and consistent with Mummolo and Nall (2016). Results from a mediation analysis following Imai et al. (2011) show that the proportion of the effect of protests on white racial resentment today mediated by net white migration in the 1970s is statistically indistinguishable from zero. Though it could be the case that white liberals versus white conservatives differentially sort across protest versus nonprotest counties, work by Mummolo and Nall (2016) show that sorting on the basis of political views is also quite small. As a result, it does not seem that sorting alone can explain the entirety of the results. $^{12}$

In sum, the results demonstrate that the civil rights movement continues to shape contemporary American politics. Moreover, the evidence suggests that the results are primarily driven through attitudinal change rather than racial or partisan polarization. These results are robust to accounting for a wide variety of alternative explanations, estimation strategies, and inference procedures. While each research design used has its limitations, the amalgamation of evidence demonstrates

\footnotetext{
${ }^{12}$ Results from the mediation analysis can be found in the Online Appendix.
} 
that social movements can engender long-run ideological change.

\section{Conclusion}

Can social movements continue to shape politics after the immediate life of the movements? Using the case of the U.S. civil rights movement, I argue and provide evidence that social movements that no longer exist today can still lead to a persistent impact on politics outside of formal institutional changes. Generating testable hypotheses from theories of intergroup relations and cultural transmission, I find that whites from counties that experienced civil rights protest activity 50 years ago tend to be more liberal today as proxied by levels of racial resentment against African Americans, support for affirmative action, and party identification. These results are robust to the inclusion of an exhaustive set of observable historical confounders, state fixed effects, independent variable operationalization, and permutation inference. Using a series of formal sensitivity analyses, I demonstrate that the correlations presented can be interpreted as a causal relationship between historical civil rights protests and contemporary political behavior.

This study contributes to work in American political development and historical political economy. Particularly, these results provide an important contrast to Acharya, Blackwell, and Sen (2016) and the study of continuity and change in American political attitudes. Though slavery may have imprinted a lasting and pernicious legacy on the status of race in America, efforts to overcome the norms and cultures created by this deleterious institution seem to have been successful to some degree. More broadly speaking, while many scholars working in historical political economy focus on the effects of institutional change on long-run political and economic development, I show how political movements during times of spectacular social upheaval can shape contemporary politics outside of institutional channels. This suggests the renewed importance of studying how social movements across a variety of contexts in American history might (or might not) change historical trajectories (Banaszak 1996; Carpenter and Moore 2014; Clemens 1997; King and Smith 2005; Lee 2002; Schickler 2016).

This study suggests promising avenues for future research at the intersection of social movements, public opinion, and political development. In today's context where the "egalitarian transformative" order seems to be under assault with the rise of racialized mass incarceration (Weaver and Lerman 2010), police killings of unarmed civilians (Soss and Weaver 2017), and white resentment (Cramer 2016), it is important to understand how new social movements such as Black Lives Matter have the potential to sustain this racial order (King and Smith 2005). Moreover, the simultaneous rise of "colorblind" societies that de-emphasize race paired with the implicit racialization of public policy suggests that there might be limits to the ability of social movements to engender persistent shifts in racial attitudes (King and Smith 2014; Tesler 2012; Tesler and Sears 2010). When the institutional and ideational underpinnings of racial egalitarianism come under deep and sustained assault, history alone will likely be insufficient to maintain a racially liberal society. This suggests that scholars should look more deeply into the institutions required to lock in a social movement's political and cultural legacies.

A natural extension of this inquiry would be to investigate how other social movements and institutional changes can either reinforce or erode progress made by past social movements. For example, a growing body of research in political science shows the importance of the women's suffrage movement for the organizational development and political mobilization of women in politics (Carpenter and Moore 2014; Corder and Wolbrecht 2016; McConnaughy 2013; Teele 2018). While the institutional victory of enfranchisement is of immense importance, this article suggests that there could have also been a much deeper legacy of the women's suffrage movement by fundamentally changing attitudes toward women. Given the argument and results in this article, future work investigating the attitudinal legacies of the women's suffrage movement would help unpack the cultural ramifications and limits of social movements.

Finally, this article emphasizes the importance of "critical junctures" in the study of political development (Pierson 2000). In this article, I showed how one such juncture in American history-the civil rights movement—created a durable shift in racial and political attitudes. But social movements are not the only drivers of change. As Mayhew (2005) points out, wars can also be a major force of change in politics. Within the context of the civil rights movement itself, scholars note how World War II was a major inflection point in black political activism (Klinkner and Smith 1999; Parker 2010). Yet at the same time, there were major limitations to the degree to which the war suppressed certain kinds of activism (Kryder 2001) and shaped whites' views toward racial equality (White 2016). Of course, this 
is but one of the many examples in which the social disruptions in American history could have profoundly transformed politics. Further study of these issues, among others, will not only enrich our understanding of periods of fundamental transition, but should also guide those who intimately participate in these historic moments.

\section{References}

Acharya, Avidit, Matthew Blackwell, and Maya Sen. 2016. “The Political Legacy of American Slavery." Journal of Politics 78(3): 621-41.

Arsenault, Raymond. 2006. Freedom Riders: 1961 and the Struggle for Racial Justice. New York: Oxford University Press.

Banaszak, Lee Ann. 1996. Why Movements Succeed or Fail: Opportunity, Culture, and the Struggle for Woman Suffrage. Princeton, NJ: Princeton University Press.

Blackwell, Matthew. 2014. "A Selection Bias Approach to Sensitivity Analysis or Causal Effects.” Political Analysis 22(2): 169-82.

Boyd, Robert, and Peter J. Richerson. 2005. The Origin and Evolution of Cultures. New York: Oxford University Press.

Branton, Regina, Valerie Martinez-Ebers, Tony E. Carey Jr., and Tetsuya Matsubayashi. 2015. "Social Protest and Policy Attitudes: The Case of the 2006 Immigrant Rallies." American Journal of Political Science 59(2): 390-402.

Broockman, David, and Joshua Kalla. 2016. "Durably Reducing Transphobia: A Field Experiment on Door-to-Door Canvassing." Science 352(6282): 220-24.

Campbell, Angus, Philip E. Converse, Warren E. Miller, and Donald E. Stokes. 1960. The American Voter. Chicago: University of Chicago Press.

Carpenter, Daniel, and Colin D. Moore. 2014. "When Canvassers Became Activists: Antislavery Petitioning and the Political Mobilization of American Women." American Political Science Review 108(3): 479-98.

Chenoweth, Erica, and Maria J. Stephan. 2008. "Why Civil Resistance Works: The Strategic Logic of Nonviolent Conflict." International Security 33(1): 7-44.

Chenoweth, Erica, and Maria J. Stephan. 2012. Why Civil Resistance Works: The Strategic Logic of Nonviolent Conflict. New York: Columbia University Press.

Clemens, Elisabeth S. 1997. The People's Lobby: Organizational Innovation and the Rise of Interest Group Politics in the United States, 1890-1925. Chicago: University of Chicago Press.

Corder, J. Kevin, and Christina Wolbrecht. 2016. Counting Women's Ballots: Female Voters from Suffrage through the New Deal. New York: Cambridge University Press.

Craemer, Thomas. 2008. "Nonconscious Feelings of Closeness toward African Americans and Support for Pro-Black Policies." Political Psychology 29(3): 407-36.

Craemer, Thomas. 2010. "Possible Implicit Mechanisms of Minority Representation.” Political Psychology 31(6): 797829.
Cramer, Katherine J. 2016. The Politics of Resentment: Rural Consciousness in Wisconsin and the Rise of Scott Walker. Chicago: University of Chicago Press.

Enos, Ryan D. 2016. "What the Demolition of Public Housing Teaches Us about the Impact of Racial Threat on Political Behavior." American Journal of Political Science 60(1): 12342 .

Gaertner, Samuel, and John Dovidio. 2000. Reducing Intergroup Bias: The Common Ingroup Identity Model. London, United Kingdom: Psychology Press.

Gaertner, Samuel L. 1996. "Revisiting the Contact Hypothesis: The Induction of a Common Ingroup Identity." International Journal of Intercultural Relations 20(3-4): 271-90.

Gaertner, Samuel L., Jeffery Mann, Audrey Murrell, and John F. Dovidio. 1989. "Reducing Intergroup Bias: The Benefits of Recategorization." Journal of Personality and Social Psychology 57(2): 239-49.

Gentzkow, Matthew. 2006. "Television and Voter Turnout." Quarterly Journal of Economics 121(3): 931-72.

Gillion, Daniel Q. 2012. "Protest and Congressional Behavior: Assessing Racial and Ethnic Minority Protests in the District." Journal of Politics 74(4): 950-962.

Green, Donald P., Bradley Palmquist, and Eric Schickler. 2002. Partisan Hearts and Minds: Political Parties and the Social Identities of Voters. New Haven, CT: Yale University Press.

Green, Donald P., and Lynn Vavreck. 2008. "Analysis of Cluster-Randomized Experiments: A Comparison of Alternative Estimation Approaches.” Political Analysis 16(2): 138-52.

Haines, Michael R. n.d. Historical, Demographic, Economic, and Social Data: The United States, 1790-2002. Census of ed. Inter-university Consortium for Political and Social Research. University of Michigan, Ann Arbor, Michigan.

Henry, P.J., and David O. Sears. 2002. "The Symbolic Racism 2000 Scale." Political Psychology 23(2): 253-83.

Imai, Kosuke, Luke Keele, Dustin Tingley, and Teppei Yamamoto. 2011. "Unpacking the Black Box of Causality: Learning about Causal Mechanisms from Experimental and Observational Studies." American Political Science Review 105(4): 765-89.

Key, V.O. 1949. Southern Politics in State and Nation. Knoxville: University of Tennessee Press.

King, Desmond S., and Rogers M. Smith. 2005. "Racial Orders in American Political Development." American Political Science Review 99(1): 75-92.

King, Desmond S., and Rogers M. Smith. 2008. "Strange Bedfollows? Polarized Politics? The Quest for Racial Equity in Contemporary America.” Political Research Quarterly 61(4): 686-703.

King, Desmond S., and Rogers M. Smith. 2011. Still a House Divided: Race and Politics in Obama's America. Princeton, NJ: Princeton University Press.

King, Desmond S., and Rogers M. Smith. 2014. "'Without Regard to Race': Critical Ideational Development in Modern American Politics." Journal of Politics 76(4): 958-71.

Klinkner, Philip A., and Rogers M. Smith. 1999. The Unsteady March: The Rise and Decline of Racial Equality in America. Chicago: University of Chicago Press. 
Kryder, Daniel. 2001. Divided Arsenal: Race and the American State during World War II. New York: Cambridge University Press.

Lee, Taeku. 2002. Mobilizing Public Opinion: Black Insurgency and Racial Attitudes in the Civil Rights Era. Chicago: University of Chicago Press.

Levendusky, Matthew S. 2018. "Americans, Not Partisans: Can Priming American National Identity Reduce Affective Polarization?" Journal of Politics 80(1): 59-70.

Madestam, Andreas, Daniel Shoag, Stan Veuger, and David Yanagizawa-Drott. 2013. "Do Political Protests Matter? Evidence from the Tea Party Movement." Quarterly Journal of Economics 128(4): 1633-85.

Mayhew, David R. 2005. "Wars and American Politics." Perspectives on Politics 3(3): 473-93.

McAdam, Doug. 1999. Political Process and the Development of Black Insurgency, 1930-1970. 2nd ed. Chicago: University of Chicago Press.

McAdam, Doug, and Yang Su. 2002. "The War at Home: The Impact of Anti-War Protests, 1965-1973." American Sociological Review 67(5): 696-721.

McConnaughy, Corrine M. 2013. The Woman Suffrage Movement in America: A Reassessment. New York: Cambridge University Press.

Mickey, Robert. 2015. Paths Out of Dixie: The Democratization of Authoritarian Enclaves in America's Deep South, 1944-1972. Princeton, NJ: Princeton University Press.

Moland, John, Jr. 2002. "The Value-Oriented Civil Rights Movement and Passive Resistance: An Expression of Civility in the Pursuit of Social Justice." Sociological Inquiry 72(3): 442-55.

Mummolo, Jonathan, and Clayton Nall. 2016. "Why Partisans Don't Sort: The Constraints on Political Segregation.” Journal of Politics 79(1): 45-59.

Nall, Clayton. 2015. “The Political Consequences of Spatial Policies: How Interstate Highways Facilitated Geographic Polarization." Journal of Politics 77(2): 394-406.

Nisbett, Richard E., and Dov Cohen. 1996. Culture of Honor: The Psychology of Violence in the South. Boulder, CO: Westview Press.

Nunn, Nathan, and Leonard Wantchekon. 2011. "The Slave Trade and the Origins of Mistrust in Africa." American Economic Review 101(7): 3221-52.

Paluck, Elizabeth Levy, and Donald P. Green. 2009. "Deference, Dissent, and Dispute Resolution: An Experimental Intervention Using Mass Media to Change Norms and Behavior in Rwanda." American Political Science Review 103(4): 622-44.

Parker, Christopher S. 2010. Fighting for Democracy: Black Veterans and the Struggle Against White Supremacy in the Postwar South. Princeton, NJ: Princeton University Press.

Pierson, Paul. 2000. "Increasing Returns, Path Dependence, and the Study of Politics." American Political Science Review 94(2): 251-67.

Ratkovic, Marc, and Dustin Tingley. 2017. "Sparse Estimation and Uncertainty with Application to Subgroup Analysis." Political Analysis 25(1): 1-40.
Schickler, Eric. 2016. Racial Realignment: The Transformation of American Liberalism, 1932-1965. Princeton, NJ: Princeton University Press.

Sears, David O., and P.J. Henry. 2003. "The Origins of Symbolic Racism." Journal of Personality and Social Psychology 85(3): 259-75.

Shickler, Eric. 2016. Racial Realignment: The Transformation of American Liberalism, 1932-1965. Princeton, NJ: Princeton University Press.

Sidanius, Jim, and Felicia Pratto. 1999. Social Dominance: An Intergroup Theory of Social Hierarchy and Oppression. Cambridge: Cambridge University Press.

Sniderman, Paul M., and Philip E. Tetlock. 1986. "Symbolic Racism: Problems of Motive Attribution in Political Analysis." Journal of Social Issues 42(2): 129-50.

Sokol, Jason. 2007. There Goes My Everything: White Southerners in the Age of Civil Rights, 1945-1975. New York: Vintage.

Soss, Joe, and Vesla Weaver. 2017. "Police Are Our Government: Politics, Political Science, and the Policing of Race-Class Subjugated Communities. " Annual Review of Political Science 20: 565-91.

Soule, Sarah A., and Susan Olzak. 2004. "When Do Movements Matter? The Politics of Contingency and the Equal Rights Amendment. " American Sociological Review 69: 473-97.

Tabellini, Guido. 2008. "The Scope of Cooperation: Values and Incentives.” Quarterly Journal of Economics 123(3): 905-50.

Teele, Dawn Langan. 2018. "How the West Was Won: Competition, Mobilization, and Women's Enfranchisement in the United States." Journal of Politics 80(2): 442-61.

Tesler, Michael. 2012. "The Spillover of Racialization into Health Care: How President Obama Polarized Public Opinion by Racial Attitudes and Race." American Journal of Political Science 56(3): 690-704.

Tesler, Michael. 2013. "The Return of Old-Fashioned Racism to White Americans' Partisan Preferences in the Early Obama Era." Journal of Politics 75(1): 110-23.

Tesler, Michael, and David O. Sears. 2010. Obama's Race: The 2008 Election and the Dream of a Post-Racial America. Chicago: University of Chicago Press.

Transue, John E. 2007. "Identity Salience, Identity Acceptance, and Racial Policy Attitudes: American National Identity as a Uniting Force." American Journal of Political Science 51(1): 78-91.

Voigtlander, Nico, and Hans-Joachim Voth. 2012. "Persecution Perpetuated: The Medieval Origins of Anti-Semitic Violence in Nazi Germany." Quarterly Journal of Economics 127(3): 1339-92.

Wallace, Sophia J., Chris Zepeda-Millan, and Michael JonesCorrea. 2014. "Spatial and Temporal Proximity: Examining the Effects of Protests on Political Attitudes." American Journal of Political Science 58(2): 433-48.

Wasow, Omar. 2017. "Do Protests Matter? Evidence from the 1960s Black Insurgency." Working paper. http://www. omarwasow.com/Protests_on_Voting.pdf.

Weaver, Vesla M., and Amy E. Lerman. 2010. "Political Consequences of the Carceral State." American Political Science Review 104(4): 817-33. 
White, Steven. 2016. “Civil Rights, World War II, and U.S. Public Opinion." Studies in American Political Development 30(1): 38-61.

Winkler, Richelle, Kenneth M. Johnson, Cheng Cheng, Jim Beaudoin, Paul R. Voss, and Katherine J. Curtis. 2013. "Age-Specific Net Migration Estimates for U.S. Counties, 1950-2010.” Applied Population Laboratory, University of Wisconsin-Madison.

Wright, Gavin. 2013. Sharing the Prize: The Economics of the Civil Rights Revolution in the American South. Cambridge, MA: Harvard University Press.

Zaller, John. 1992. The Nature and Origins of Mass Opinion. Cambridge: Cambridge University Press.

\section{Supporting Information}

Additional supporting information may be found online in the Supporting Information section at the end of the article.

A.1 Descriptive Statistics

A.2 Potential Reporting Biases

A.3 Continuous Specification

A.4 Additional Control Variables

A.5 Randomization Inference

A.6 Heterogeneous Effects 